\title{
An Analysis of Financial Distress Accuracy Models in Indonesia Coal Mining Industry: An Altman, Springate, Zmijewski, Ohlson and Grover Approaches
}

\author{
M. Noor Salim ${ }^{1}$ \& (D) $\triangle$ and Dhermawan Ismudjoko 8 (D) \\ ${ }^{12}$ Mercu Buana University, Indonesia \\ $\triangle$ Corresponding Author: M. Noor Salim, E-mail: 1975801189@mercubuana.ac.id
}

\section{ARTICLE INFORMATION}

Received: April 08, 2021

Accepted: June 10, 2021

Volume: 3

Issue: 2

DOI: $10.32996 /$ jefas.2021.3.2.1

\section{KEYWORDS}

Financial distress, Altman, Springate, Zmijewski, Ohlson, Grover

\section{ABSTRACT}

The purpose of this research is to determine companies financial distress base on Altman, Springate, Zmijewski, Ohlson and Grover Models and to assess the accuracy of those five prediction models in coal mining sector firms listed in Indonesia Stock Exchange (IDX) for the period 2015 - 2019. This research has 22 samples of 23 coal mining firms listed in IDX base on the purposive sampling technique. This study is a descriptive design using quantitative and panel data. The research data is analyzed using the Kruskal Wallis test because there are more than two prediction models to compare and the data are not normally distributed. The result indicates that the Modified Altman and Ohlson Models are the most accurate predictive models because these models have the highest accuracy rate of $90.91 \%$, followed by Zmijewski Model, which has an accuracy rate of $86.36 \%$, then Grover Model has $81.82 \%$ accuracy rate, and the lowest prediction rate is Springate Model with the value of $63.64 \%$.

\section{Introduction ${ }^{1}$}

Coal prices fluctuation from 2010 to 2020 and high-cost operation have made the coal mining industry included in the highrisk business category. The decline of coal prices will affect company profits and if it continues getting losses, it will have an impact on company bankruptcy. The coal price shown in Picture 1 indicates that coal price falls in two periods, mainly from 2012 to 2016 and 2018 to 2020 . Furthermore, this phenomenon impacts company profit shown in Table 1 that indicated some companies like Atlas Resource, Bumi Resources, Perdana Karya Perkasa, and SMR Utama have negative profits during 2015 2019. This signal can be assumed as an early warning of financial distress before bankruptcy occurs.

Research on corporate financial distress in Indonesia has been published. However, this study has some differences compared to previous research. The first point is about the differences in the object. Safitri and Hartono (2014) have been researched the financial sector. Puspita Sari (2015) analysed the transportation sector. Widyanty (2018) studied the LQ-45 companies. Primasari (2018) analysed financial distress in the consumer goods sector. Imelda \& Alodia (2017) conducted research in the manufacture industry. The object of this research is the coal mining industry.

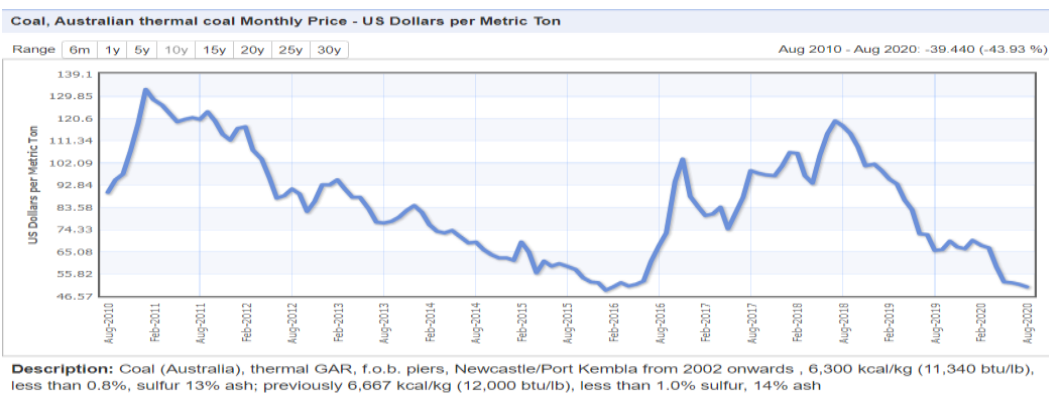

Picture 1. Coal price during 2010 to 2020 (source: www.indexmundi.com)

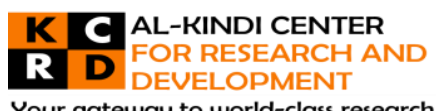

Your gateway to world-class research

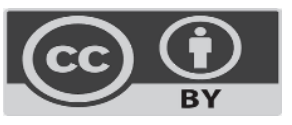

Published by Al-Kindi Center for Research and Development. Copyright (c) the author(s). This open access article is distributed under a Creative Commons Attribution (CC-BY) 4.0 license 
Table 1. List of ten coal companies profit and loss (source: www.idx.co.id)

\begin{tabular}{lllllllll}
\hline $\mathbf{N}$ & Company & Code & Unit & $\mathbf{2 0 1 5}$ & $\mathbf{2 0 1 6}$ & $\mathbf{2 0 1 7}$ & $\mathbf{2 0 1 8}$ & $\mathbf{2 0 1 9}$ \\
\hline 1 & Adaro Energy & ADRO & USD (mio) & 151 & 341 & 536 & 478 & 435 \\
\hline 2 & Atlas Resources & ARII & USD (mio) & $(26)$ & $(25)$ & $(16)$ & $(28)$ & $(6)$ \\
\hline 3 & Bumi Resources & BUMI & USD (mio) & $(2185)$ & 120 & 243 & 158 & 9 \\
\hline 4 & Harum Energy & HRUM & USD (mio) & $(19)$ & 18 & 56 & 40 & 20 \\
\hline 5 & Indika Energy & INDY & USD (mio) & $(77)$ & $(104)$ & 322 & 98 & 5 \\
\hline 6 & Perdana Karya Perkasa & PKPK & IDR (bio) & $(62)$ & $(14)$ & $(10)$ & $(4)$ & $(42)$ \\
\hline 7 & Bukit Asam & PTBA & IDR (bio) & 2037 & 2024 & 4574 & 5121 & 4040 \\
\hline 8 & Petrosea & PTRO & USD (mio) & $(13)$ & $(8)$ & 12 & 23 & 31 \\
\hline 9 & SMR Utama & SMRU & IDR (bio) & $(20)$ & $(17)$ & 2 & $(70)$ & $(187)$ \\
\hline 10 & Toba Bara Sejahtera & TOBA & USD (mio) & 26 & 15 & 41 & 68 & 44 \\
\hline
\end{tabular}

The second point is about the different models used in the study. Zainal Abidin Putera et al. (2016) used Altman, Spingate, and Ohlson Models. Salim \& Sudiono (2017) applied Altman, Springate, and Zmijewski Models. Hungan and Sawitri (2018) analysed Grover and Springate Models. Piscestalia \& Maswar (2019) use four models are Springate, Ohlson, Zmijewski, and Grover. This research uses five predictor models. They are Altman, Springate, Zmijewski, Ohlson, and Grover.

The third point is about the gap of the best predictor model. Fatmawati (n.d.) stated that the Zmijewski Model is the best predictor model compared to Springate and Altman. Puspita Sari (2015) said that Altman Model is more accurate than Springate, Grover, and Zmijewski Models. Edi and Tania (2018) and Priambodo \& Pustikaningsih (2018) stated that Springate Model has higher accuracy than Grover, Altman, and Zmijewski Models.

The conclusion of this research is expected can be used by management for internal evaluation. Investors and creditors can assess the corporate financial performance prior to commencing investment. The government is expected to review and establish mining regulation to help the company grow or survive during coal price pressure.

\section{Literature Review}

\subsection{Definition of Financial Distress}

According to Wruck (1990), the definition of financial distress is a situation when net cash flow is not sufficient to cover current debts. An extreme situation of financial distress is bankruptcy which can be very expensive, involving legal fees and forcing the company to release its assets at a depressed price.

\subsection{Indicators of Financial Distress}

Wruck (1990) provides several general indicators of corporate financial distress, they are continuous dividend reduction or even fail to provide dividend at all, unable to pay operations then impact the closure of several branches, layoffs occur to save the company from larger losses, resignation or sacking their executive, and falling of stock price as an indicator of the market value of the company. According to Altman (1968), Whitaker (1999) and Mumford (2003), financial distress occurs when a company cannot pay its debts. According to Kida (1980) and Mutchler (1985), corporate financial distress occurs if the company at least has one signal among some indicators such as negative working capital in the recent year, operating loss during three years before the bankruptcy, the deficit of retained earnings in the third year before bankruptcy, negative profits in three years before the bankruptcy.

Based on the above literature review, the financial distress indicators used in this research happen when the company has negative profits for three or more consecutive years, reduce or fail to pay a dividend at all, and increment of debt to equity ratio (DER).

\subsection{Modified Altman Z"-Score Model}

The most popular model for predicting corporate failure is the Z-score formula was developed in 1968 by Edward I. Altman, an assistant professor of finance at New York University. Altman uses the Multiple Discriminant Analysis (MDA) technique to predict company bankruptcy. In 1983, Altman revised his model to produce Z'-score by adjusting the model for the private company sector model since the previous Z-score was only used for going public manufacture. Furthermore, Altman modified his model to produce Z"-score by removing sales to total assets variable (Altman, 1968). EBIT to total assets ratio has the most contribution at this model version (Altman et al., 2017, p. 136). Altman Modification Model has cut-off value 2.60 and 1.10. The company suffers financial distress if the cut-off value less than 1.10. If the cut-off value is between 1.10 and 2.60 , the company sits in a grey area position (Maina \& Sakwa, 2010, p. 485). 


\subsection{Springate S-Score Model}

The Springate Model was developed in 1978 use MDA technique to select four ratios from 19 popular financial ratios. They are working capital to total assets, EBIT to total assets, EBIT to current liabilities, and sales to total assets (Ari Rachmad, 2021). S-score has a cut-off value 0.862. If S-score is less than cut-off value, the company is predicted to be in financial distress (Primasari, 2018, p. 28).

\subsection{Zmijewski X-Score Model}

Zmijewski (1984) expanded his study in predicting bankruptcy by analysing return on assets, debt ratio, and current ratio. X-score has a cut-off value 0 . If $X$-score is greater than the cut-off value, the company is predicted in financial distress condition (Edi $\&$ Tania, 2018).

\subsection{Ohlson O-Score Model}

Ohlson (1980) published his research use logit or multiple logistic regression techniques to construct a bankruptcy predictor model. He uses a cut-off value greater than 0.38 to predict the company's financial distress condition (Safitri \& Hartono, 2014, p. 330).

\subsection{Grover G-Score Model}

The Grover Model is created by redesigning and evaluating the Altman's Model by adding 13 new financial ratios use 35 bankrupt and 35 non-bankrupt companies in 1982 - 1996. The cut-off value for a bankrupt company if G-score produces value less than or equal to -0.02 . Meanwhile, cut off more or equal to 0.01 indicate the non-bankrupt company (Salim \& Sudiono, 2017, p. 381).

\section{Theoretical Framework and Hypothesis}

The research framework in this research as follows:

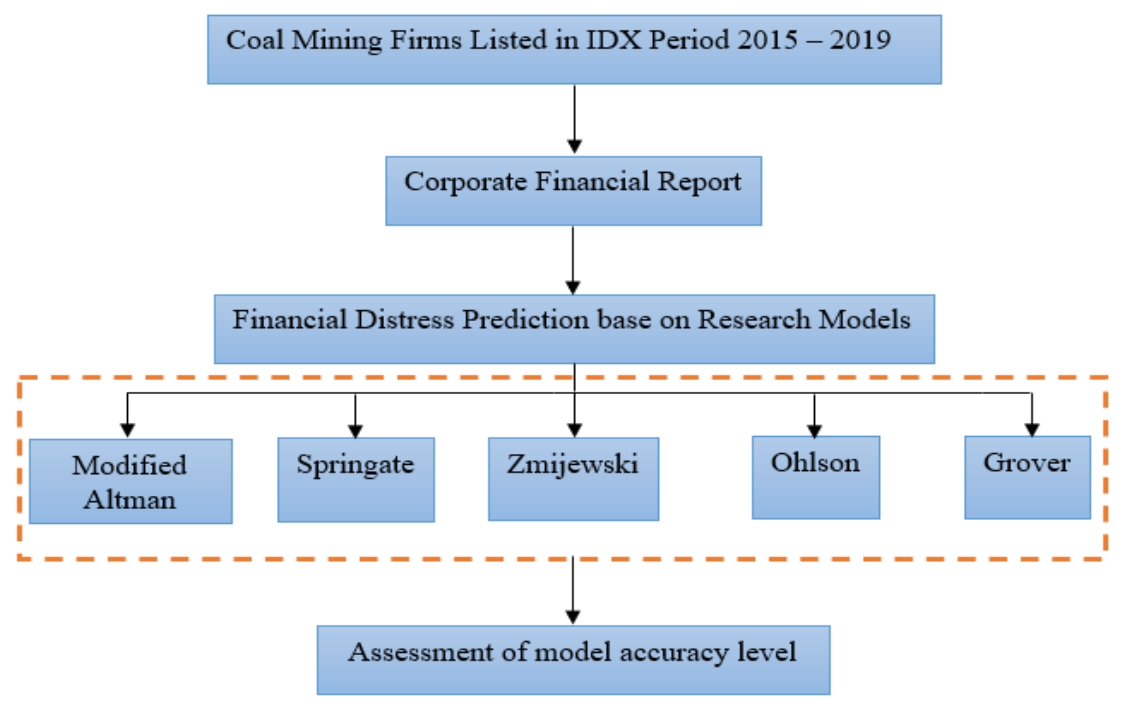

Picture 2. Framework

The hypotheses are formulated for this research as follow:

$\mathrm{H}_{1}$ : There are differences in financial distress prediction result using Modified Altman, Springate, Zmijewski, Ohlson, and Grover Models.

$\mathrm{H}_{2}$ : The Modified Altman Model is the most accurate model in predicting financial distress compared to Springate, Zmijewski, Ohlson, and Grover Models.

$\mathrm{H}_{3}$ : The Springate Model is the most accurate model in predicting financial distress compared to Modified Altman, Zmijewski, Ohlson, and Grover Models.

$\mathrm{H}_{4}$ : The Zmijewski Model is the most accurate model in predicting financial distress compared to Modified Altman, Springate, Ohlson, and Grover Models. 
$\mathrm{H}_{5}$ : The Ohlson Model is the most accurate model in predicting financial distress compared to Modified Altman, Springate, Zmijewski and Grover Models.

$\mathrm{H}_{6:}$ The Grover Model is the most accurate model in predicting financial distress compared to Modified Altman, Springate, Zmijewski and Ohlson Models.

\section{Research Methods}

According to two criteria, the number of samples of this research is 22 of 23 populations from coal mining firms listed in IDX based on the purposive sampling technique. First, a coal mining company listed in IDX consecutively in the $2015-2019$ period. Second, corporate financial statements are issued and complete audited during the period 2015 - 2019.

This study is a descriptive design using quantitative and secondary data type. Data are cross-section and time-series (panel data) with 22 samples for 5 years observation, so 110 total audited financial statements are to be explored to analyse financial ratios. The operational variables in Picture 3 are used in this research, as follow:

1. WCTA (Working Capital / Total Assets)

This variable is used to measure the company's liquidity. Altman, Springate, Ohlson, and Grover Models use this variable. The higher WCTA ratio indicates the greater company working capital from total assets and expected will increase the company profits. This variable can be measured using the company's financial statement data.

2. RETA (Retained Earnings / Total Assets)

RETA is used to measure the company's cumulative profitability. This variable is only used in Altman Model.

3. EBITTA (Earnings Before Interest and Taxes / Total Assets)

EBITTA is used to measure the company's profitability. This variable is used in the Altman, Springate, and Grover Models.

4. BVETL (Book Value of Equity / Total Liabilities)

BVETL is used to determine the company's value by investors in the capital market. This variable is only used in Altman Model.

5. SATA (Sales / Total Assets)

SATA is used to determine the company's ability to generate sales by existing assets. This variable is only used in Springate Model.

6. EBTCL (Earnings Before Taxes / Current Liabilities)

EBTCL is used to measure company's profitability. EBT data is obtained from the profit or loss statement. This variable is only used in Springate Model.

7. SIZE (Log (Total Assets / GNP Price Level Index)

SIZE is used to measure the company's size. This variable is only used in Ohlson Model. Gross National Product (GNP) price level index data is obtained in www.bps.go.id.

8. TLTA (Total Liabilities / Total Assets)

TLTA is a variable to measure the company's total liquidity. This variable is used in Ohlson and Zmijewski Models. This ratio is determined to measure the company's leverage. The company is in difficult financial position when this ratio continues larger and will increase risk of inability to pay company's liabilities.

9. CLCA (Current Liabilities / Current Assets)

CLCA is used to measure the company's short-term liquidity. This variable is only used in Ohlson Model. If current liabilities exceed current assets, the company will difficult to pay the short-term debt.

10. NITA (Net Income / Total Assets)

NITA is used to measure the company's profitability. This variable is used in Zmijewski, Ohlson, and Grover Models. Net income and total assets are obtained in the profit or loss statement and balance sheet.

11. FUTL (Cash Flow from Operation / Total Liabilities)

FUTL is used to measure the company's liquidity and determine company's ability to generate sufficient cash to pay liabilities. This variable is only used in Ohlson Model. The data is obtained in cash flow statement and balance sheet.

12. INTWO

INTWO is used to measure the company's profitability. This variable is only used in Ohlson Model. If during the last two years the company getting losses, it may be financial distress condition.

13. OENEG

OENEG is used to measure the company's liquidity. This model is only present in Ohlson Model. If total debt exceeds total assets, the company is likely in financial distress condition.

14. CHIN 
CHIN is used to measure the changing of company's profitability. This model is only present in Ohlson Model. The data is obtained in profit or loss statement. This variable is determined by measuring the changing of net income during the last two years.

15. CACL (Current Assets / Current Liabilities)

$\mathrm{CACL}$ is used to determine the effectiveness of current assets to pay current liabilities. This variable is only present in Zmijewski Model. The data is obtained in company's balance sheet.

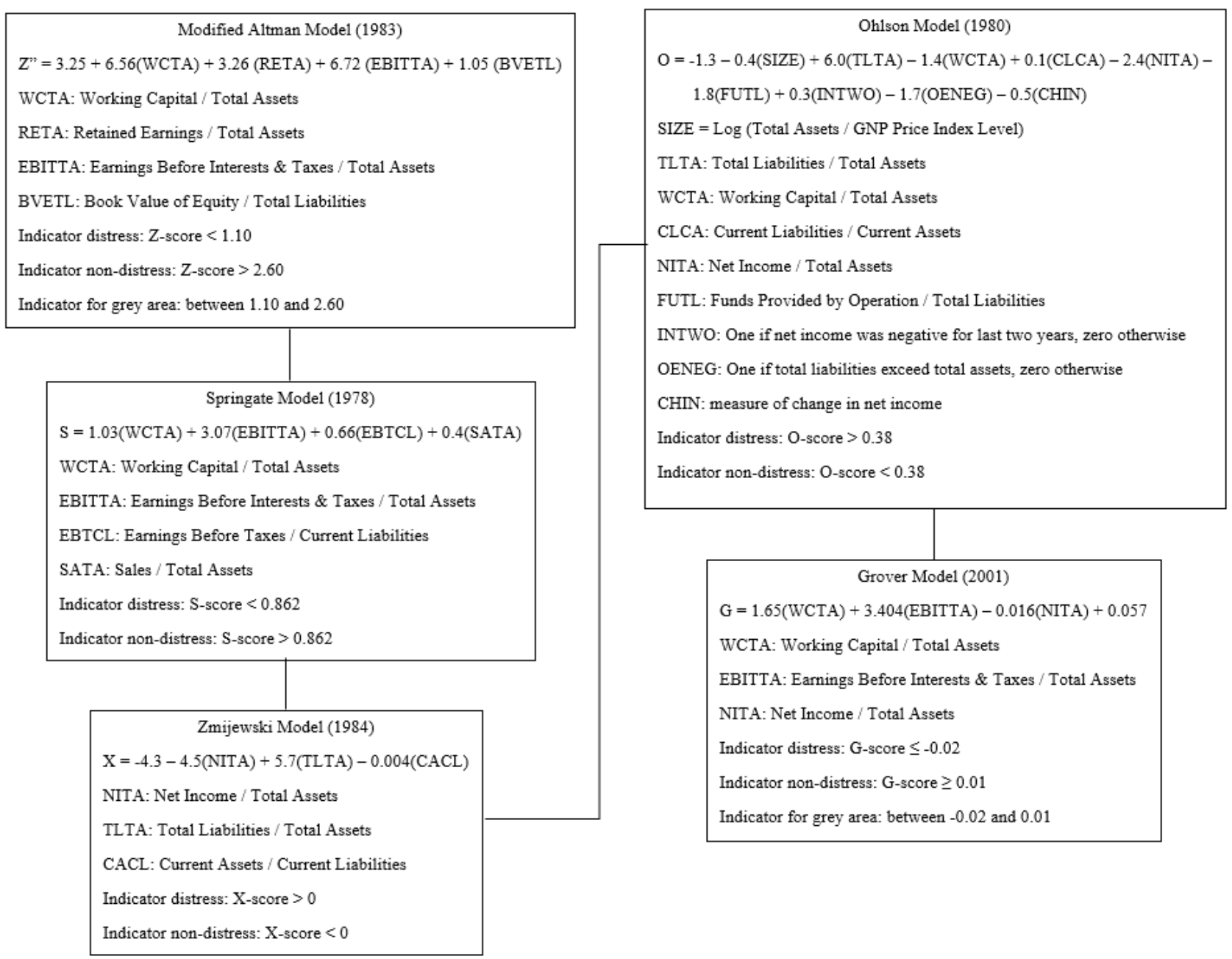

Picture 3. Operational variables

\section{Findings and Discussion}

\subsection{Descriptive Statistic Analysis}

The descriptive statistic in Table 2 is measured using minimum, maximum, mean, and standard deviation of 22 research samples of each model. For example, Modified Altman Model has a mean value of 6.9568, a minimum value of -2.4 , and a maximum value of 15.88 as well as the other models. The standard deviation in Modified Altman Model is the highest value compared to the other four models. It indicates that samples in Modified Altman Model are more varied and more dispersed than the mean. On the other hand, the Grover Models has the lowest standard deviation value of 0.68815. It indicates that samples data in Grover Model are more homogeneous. 
Table 2. Descriptive statistics result

\begin{tabular}{lccccc}
\hline Model & N & Minimum & Maximum & Mean & Std. Deviation \\
\hline Modified Altman & 22 & $(2,41)$ & 15,88 & 6,9568 & 4,39125 \\
\hline Springate & 22 & $(15,81)$ & 3,33 & 0,2164 & 3,77836 \\
\hline Zmijewski & 22 & $(4,18)$ & 3,45 & $(1,8700)$ & 1,84454 \\
\hline Ohlson & 22 & $(7,34)$ & 2,40 & $(3,3977)$ & 2,29656 \\
\hline Grover & 22 & $(0,86)$ & 2,03 & 0,6084 & 0,68815 \\
\hline
\end{tabular}

\subsection{Financial Condition}

As mentioned earlier, the financial distress indicators used in this research when for three or more consecutive years the company has negative profits, reduce or fail to pay dividend at all, and increase debt to equity ratio (DER).

Table 3 indicates that there are two companies suffer financial distress. They are ARII and PKPK. While the other 20 companies in healthy financial condition. ARII and PKPK challenging to manage the indicators to avoid financial distress. Both companies have negative profits and fail to pay dividends for five years. ARII has to increase DER during $2015-2018$ from $3.28 \%$ to $34.0 \%$. PKPK has better DER than ARII but relatively increase from $1.05 \%$ to $4.07 \%$ for five years. These conditions trigger financial distress and if they can not manage them, bankruptcy cannot be prevented. The decline of coal price must impact these conditions but some companies can survive because they have adequate financial management.

Table 3. Financial distress companies base on profit, dividend and DER indicators

\begin{tabular}{|c|c|c|c|c|}
\hline Company & Year & Profit & Dividend & DER (\%) \\
\hline \multirow{5}{*}{$\begin{array}{c}\text { ARII } \\
\text { (USD mio) }\end{array}$} & 2015 & -26 & 0 & 3.28 \\
\hline & 2016 & -25 & 0 & 4.88 \\
\hline & 2017 & -16 & 0 & 7.18 \\
\hline & 2018 & -28 & 0 & 34.00 \\
\hline & 2019 & -6 & 0 & 6.91 \\
\hline \multirow{5}{*}{$\begin{array}{c}\text { PKPK } \\
\text { (IDR bio) }\end{array}$} & 2015 & -62 & 0 & 1.05 \\
\hline & 2016 & -14 & 0 & 1.26 \\
\hline & 2017 & -10 & 0 & 1.32 \\
\hline & 2018 & -4 & 0 & 1.31 \\
\hline & 2019 & -42 & 0 & 4.07 \\
\hline
\end{tabular}

\subsection{Financial Distress Model Analysis}

The financial ratio processed from the financial statement is an effective tool to describe the condition of the company. It is used as operational variables contained in each prediction model. The results of this research using calculation of model's formula and summarized in Table 4.

According to The Modified Altman Model shown in Table 4, two companies have an average Z"-score below 1.10. ARII and BUMI are predicted in difficult financial condition. ARII has Z" -score of -0.9833 and BUMI has Z"-score of -2.4054 .

The calculation result base on Springate Model has predicted 10 companies have financial problem, more than the Modified Altman approach. ARII, BUMI, DEWA, DSSA, GTBO, INDY, PKPK, PTRO, SMMT, and SMRU have average S-score below 0.862. 
The Zmijewski approach indicates that three companies have financial distress situation. ARII, BUMI, and DOID have an average X-score > 0. ARII has an average X-score 0.7982, BUMI has 3.4523, and DOID has 0.2295.

The calculation result using Ohlson Model stated that ARII and BUMI have financial difficulties. Both companies have an Oscore of more than 0.38 as the cut-off value. ARII has O-score 0.7982 and BUMI has 3.4523. The Ohlson Model's calculation has a similar conclusion with the Modified Altman Model, which states that ARII and BUMI are in financial distress.

Based on Grover Model result, four of 22 companies have financial problems due to their average G-score less than -0.02 . The distressed companies are ARII, BUMI, SMMT, and SMRU.

The calculation result mentioned in Table 4 indicates that five models have different results, but all models have the same prediction that ARII and BUMI will have financial distress problems.

Table 4. Model Prediction result

\begin{tabular}{|c|c|c|c|c|c|c|}
\hline No & Code & Z"-Score & S-Score & X-Score & O-Score & G-Score \\
\hline \multirow{2}{*}{1} & \multirow{2}{*}{ ADRO } & 7.1312 & 1.1819 & $(2.1762)$ & $(4.3714)$ & 0.6132 \\
\hline & & Safe zone & Safe zone & Safe zone & Safe zone & Safe zone \\
\hline \multirow{2}{*}{2} & \multirow{2}{*}{ ARII } & $(0.9833)$ & $(0.6201)$ & 0.7982 & 1.1045 & $(0.8591)$ \\
\hline & & Distress & Distress & Distress & Distress & Distress \\
\hline \multirow{2}{*}{3} & \multirow{2}{*}{ BSSR } & 8.6694 & 2.3280 & (3.3679) & $(5.4958)$ & 1.1488 \\
\hline & & Safe zone & Safe zone & Safe zone & Safe zone & Safe zone \\
\hline \multirow{2}{*}{4} & \multirow{2}{*}{ BUMI } & $(2.4054)$ & $(0.3728)$ & 3.4523 & 2.3993 & $(0.6143)$ \\
\hline & & Distress & Distress & Distress & Distress & Distress \\
\hline \multirow{2}{*}{5} & \multirow{2}{*}{ BYAN } & 7.0469 & 1.9935 & $(1.8314)$ & $(3.4588)$ & 1.1931 \\
\hline & & Safe zone & Safe zone & Safe zone & Safe zone & Safe zone \\
\hline \multirow{2}{*}{6} & \multirow{2}{*}{ DEWA } & 4.0142 & 0.3695 & $(4.1765)$ & $(4.2917)$ & 0.1396 \\
\hline & & Safe zone & Distress & Safe zone & Safe zone & Safe zone \\
\hline \multirow{2}{*}{7} & \multirow{2}{*}{ DOID } & 5.3631 & 0.9287 & 0.2295 & (1.1988) & 0.7552 \\
\hline & & Safe zone & Safe zone & Distress & Safe zone & Safe zone \\
\hline \multirow{2}{*}{8} & \multirow{2}{*}{ DSSA } & 6.1902 & 0.7588 & (1.6198) & (3.2023) & 0.4657 \\
\hline & & Safe zone & Distress & Safe zone & Safe zone & Safe zone \\
\hline \multirow{2}{*}{9} & \multirow{2}{*}{ GEMS } & 7.8374 & 1.5720 & $(2.2522)$ & $(4.0637)$ & 1.0095 \\
\hline & & Safe zone & Safe zone & Safe zone & Safe zone & Safe zone \\
\hline \multirow{2}{*}{10} & \multirow{2}{*}{ GTBO } & 9.3134 & $(2.2122)$ & $(2.9132)$ & $(4.1065)$ & 0.0823 \\
\hline & & Safe zone & Distress & Safe zone & Safe zone & Safe zone \\
\hline \multirow{2}{*}{11} & \multirow{2}{*}{ HRUM } & 15.8782 & 1.4323 & $(3.8020)$ & $(2.9846)$ & 1.2122 \\
\hline & & Safe zone & Safe zone & Safe zone & Safe zone & Safe zone \\
\hline \multirow{2}{*}{12} & \multirow{2}{*}{ INDY } & 5.7808 & 0.6036 & $(0.5631)$ & $(2.2738)$ & 0.5165 \\
\hline & & Safe zone & Distress & Safe zone & Safe zone & Safe zone \\
\hline
\end{tabular}




\begin{tabular}{|c|c|c|c|c|c|c|}
\hline \multirow{2}{*}{13} & \multirow{2}{*}{ ITMG } & 10.2951 & 1.9830 & (3.2436) & (5.7049) & 1.1954 \\
\hline & & Safe zone & Safe zone & Safe zone & Safe zone & Safe zone \\
\hline \multirow{2}{*}{14} & \multirow{2}{*}{ KKGI } & 12.8064 & 1.4280 & (3.4085) & $(5.7367)$ & 0.7321 \\
\hline & & Safe zone & Safe zone & Safe zone & Safe zone & Safe zone \\
\hline \multirow{2}{*}{15} & \multirow{2}{*}{ MBAP } & 13.4593 & 3.3336 & (4.0827) & (7.3391) & 2.0309 \\
\hline & & Safe zone & Safe zone & Safe zone & Safe zone & Safe zone \\
\hline \multirow{2}{*}{16} & \multirow{2}{*}{$\mathrm{MYOH}$} & 11.6064 & 2.3516 & (3.3648) & (6.1236) & 1.4614 \\
\hline & & Safe zone & Safe zone & Safe zone & Safe zone & Safe zone \\
\hline \multirow{2}{*}{17} & \multirow{2}{*}{ PKPK } & 2.9411 & (15.8081) & $(0.1262)$ & (1.0060) & 0.2264 \\
\hline & & Safe zone & Distress & Safe zone & Safe zone & Safe zone \\
\hline \multirow{2}{*}{18} & \multirow{2}{*}{ PTBA } & 8.4017 & 1.8582 & (2.8930) & (5.1291) & 1.1380 \\
\hline & & Safe zone & Safe zone & Safe zone & Safe zone & Safe zone \\
\hline \multirow{2}{*}{19} & \multirow{2}{*}{ PTRO } & 6.5028 & 0.6945 & $(0.9261)$ & (3.2221) & 0.5409 \\
\hline & & Safe zone & Distress & Safe zone & Safe zone & Safe zone \\
\hline \multirow{2}{*}{20} & \multirow{2}{*}{ SMMT } & 4.1145 & $(0.0589)$ & (2.0625) & (2.6628) & $(0.1623)$ \\
\hline & & Safe zone & Distress & Safe zone & Safe zone & Distress \\
\hline \multirow{2}{*}{21} & \multirow{2}{*}{ SMRU } & 2.9980 & $(0.2641)$ & (0.9770) & (3.0179) & $(0.0650)$ \\
\hline & & Safe zone & Distress & Safe zone & Safe zone & Distress \\
\hline \multirow{2}{*}{22} & \multirow{2}{*}{ TOBA } & 6.0883 & 1.2794 & (1.8341) & $(2.8647)$ & 0.6239 \\
\hline & & Safe zone & Safe zone & Safe zone & Safe zone & Safe zone \\
\hline \multicolumn{2}{|c|}{ Total Safe zone } & 20 & 12 & 19 & 20 & 18 \\
\hline \multicolumn{2}{|c|}{ Total Distress } & 2 & 10 & 3 & 2 & 4 \\
\hline
\end{tabular}

\subsection{Different Test}

A statistical difference test is carried out to determine the significance of the five prediction models. The different test method can be done using ANOVA test or Kruskal Wallis test because this research has more than two sample groups. The ANOVA test should be chosen if the data have a normal distribution. Otherwise, The Kruskal Wallis test is the option if the data are not normally distributed.

Table 5. Test of normality result

\begin{tabular}{lcccccc}
\hline \multicolumn{7}{c}{ Tests of Normality } \\
\hline \multicolumn{7}{c}{ Kolmogorov-Smirnov ${ }^{\text {a }}$} \\
Statistic & df & Sig. & Statistic & df & Sig. \\
\hline Financial distress & 0.489 & 550 & $\mathbf{0 . 0 0 0}$ & 0.495 & 550 & $\mathbf{0 . 0 0 0}$ \\
\hline a. Lilliefors Significance Correction & & & & & \\
\hline
\end{tabular}


Table 5 shows that Kolmogorov-Smirnov and Shapiro-Wilk normality test have a significance value of 0.000 . Due to a significance value less than 0.05 , it can be concluded that the data are not normally distributed. The Kruskal Wallis test can be performed to determine different test.

The hypothesis used in this test is as follows:

$\mathrm{H}_{0}$ : There is no difference in the prediction of financial distress using Altman, Springate, Zmijewski, Ohlson, and Grover Models for coal mining issuers in 2015 - 2019.

$\mathrm{H}_{\mathrm{a}}$ : There are differences in the prediction of financial distress using Altman, Springate, Zmijewski, Ohlson, and Grover Models for coal mining issuers in $2015-2019$.

By a significance level of less than $0.05, \mathrm{H}_{0}$ is rejected and it is concluded that the prediction result is significantly different, whereas if the significance level more than 0.05 , then $\mathrm{H}_{0}$ is not rejected and it is concluded that there is no difference is prediction result.

Table 6. Kruskal Wallis test result

\begin{tabular}{llc}
\hline \multicolumn{3}{c}{ Test Statistics $^{\mathbf{a}, \mathbf{b}}$} \\
\hline & Kruskal-Wallis H & Financial distress \\
\hline & df & 67.322 \\
\hline & Asymp. Sig. & $\mathbf{0 . 0 0 0}$ \\
\hline a. Kruskal Wallis Test & & \\
\hline b. Grouping Variable: Metode & \\
\hline
\end{tabular}

Base on the analysis results in Table 6 , the significance value is 0.000 or less than 0.05 . It can be concluded that $\mathrm{H}_{0}$ is rejected and it means the five models have a significant difference.

\subsection{Accuracy Rate of Financial Distress Models}

The previous analysis result state that the five models have different prediction results. The following Table 7 compares the accuracy level of the five prediction models compared with a real condition as shown previously in Table 3.

The measurement result in Table 7 indicates that Modified Altman and Ohlson Model have the same accuracy rate of $90.91 \%$ with an error measurement of $9.09 \%$. These models are the most accurate rate compared to other models, followed by Zmijewski Model that has an accuracy rate of $86.36 \%$ and error measurement of $13.64 \%$. Grover Model has an accuracy rate and error measurement of $81.82 \%$ and $18.18 \%$, respectively. Springate Model has the lowest accuracy rate of $63.64 \%$ and the highest error measurement of $36.36 \%$.

Table 7. Accuracy rate of prediction models

\begin{tabular}{|c|c|c|c|c|c|c|}
\hline \multirow{2}{*}{ No } & \multirow{2}{*}{ Code } & \multicolumn{5}{|c|}{ Measurement Accuracy of Each Models } \\
\hline & & Mod. Altman & Springate & Zmijewski & Ohlson & Grover \\
\hline 1 & ADRO & Correct & Correct & Correct & Correct & Correct \\
\hline 2 & ARII & Correct & Correct & Correct & Correct & Correct \\
\hline 3 & BSSR & Correct & Correct & Correct & Correct & Correct \\
\hline 4 & BUMI & Incorrect & Incorrect & Incorrect & Incorrect & Incorrect \\
\hline 5 & BYAN & Correct & Correct & Correct & Correct & Correct \\
\hline
\end{tabular}




\begin{tabular}{|c|c|c|c|c|c|c|}
\hline 6 & DEWA & Correct & Incorrect & Correct & Correct & Correct \\
\hline 7 & DOID & Correct & Correct & Incorrect & Correct & Correct \\
\hline 8 & DSSA & Correct & Incorrect & Correct & Correct & Correct \\
\hline 9 & GEMS & Correct & Correct & Correct & Correct & Correct \\
\hline 10 & GTBO & Correct & Incorrect & Correct & Correct & Correct \\
\hline 11 & HRUM & Correct & Correct & Correct & Correct & Correct \\
\hline 12 & INDY & Correct & Incorrect & Correct & Correct & Correct \\
\hline 13 & ITMG & Correct & Correct & Correct & Correct & Correct \\
\hline 14 & KKGI & Correct & Correct & Correct & Correct & Correct \\
\hline 15 & MBAP & Correct & Correct & Correct & Correct & Correct \\
\hline 16 & MYOH & Correct & Correct & Correct & Correct & Correct \\
\hline 17 & PKPK & Incorrect & Correct & Incorrect & Incorrect & Incorrect \\
\hline 18 & PTBA & Correct & Correct & Correct & Correct & Correct \\
\hline 19 & PTRO & Correct & Incorrect & Correct & Correct & Correct \\
\hline 20 & SMMT & Correct & Incorrect & Correct & Correct & Incorrect \\
\hline 21 & SMRU & Correct & Incorrect & Correct & Correct & Incorrect \\
\hline 22 & TOBA & Correct & Correct & Correct & Correct & Correct \\
\hline \multicolumn{2}{|c|}{ Total Correct } & 20 & 14 & 19 & 20 & 18 \\
\hline \multicolumn{2}{|c|}{ \% Correct } & $90.91 \%$ & $63,64 \%$ & $86.36 \%$ & $90.91 \%$ & $81.82 \%$ \\
\hline \multicolumn{2}{|c|}{ Error measurement } & $9,09 \%$ & $36,36 \%$ & $13,64 \%$ & $9,09 \%$ & $18,18 \%$ \\
\hline
\end{tabular}

\subsection{Hypothesis Test}

The hypothesis test in this study is based on the result of statistical tests that have been carried out. Hypothesis test 1 is conducted a different test using Kruskal Wallis test, while the testing of hypotheses 2 to 6 is based on the result of the model's accuracy in predicting financial distress. The following Table 8 is the summary of hypothesis test results to answer this research.

\section{Table 8. Summary of hypothesis test result}

\begin{tabular}{|c|c|c|c|}
\hline No & Hypothesis & Result & Conclusion \\
\hline 1 & $\begin{array}{l}\text { There are differences of financial distress prediction result using Modified } \\
\text { Altman, Springate, Zmijewski, Ohlson, and Grover Models for coal mining } \\
\text { sector listed in IDX period } 2015-2019 \text {. }\end{array}$ & $\begin{array}{l}\text { Sig. Kruskal Wallis test: } \\
0,000\end{array}$ & Accepted \\
\hline 2 & $\begin{array}{l}\text { The Modified Altman Model is the most accurate model in predicting } \\
\text { financial distress compared to Springate, Zmijewski, Ohlson, and Grover. }\end{array}$ & $\begin{array}{l}\text { - Accuracy: } 90,91 \% \\
\text { - Error: } 9.09\end{array}$ & Accepted \\
\hline 3 & $\begin{array}{l}\text { The Springate Model is the most accurate model in predicting financial } \\
\text { distress compared to Modified Altman, Zmijewski, Ohlson, and Grover. }\end{array}$ & $\begin{array}{l}\text { - } \\
\text { - } \\
\text { Ecror: } 36,36 \%\end{array}$ & Rejected \\
\hline 4 & $\begin{array}{l}\text { The Zmijewski Model is the most accurate model in predicting financial } \\
\text { distress compared to Modified Altman, Springate, Ohlson, and Grover. }\end{array}$ & $\begin{array}{l}\text { - } \quad \text { Accuracy: } 86,36 \\
\text { - } \quad \text { Error: } 13,64\end{array}$ & Rejected \\
\hline
\end{tabular}




\begin{tabular}{cllll}
\hline 5 & $\begin{array}{l}\text { The Ohlson Model is the most accurate model in predicting financial } \\
\text { distress compared to Modified Altman, Springate, Zmijewski and Grover. }\end{array}$ & $\begin{array}{l}\text { Accuracy: } 90,91 \% \\
\text { Error: } 9.09\end{array}$ & Accepted \\
\hline 6 & $\begin{array}{l}\text { The Grover Model is the most accurate model in predicting financial } \\
\text { distress compared to Modified Altman, Springate, Zmijewski and Ohlson. }\end{array}$ & $\begin{array}{l}\text { Accuracy: } 81,82 \% \\
\text { Error: } 18,18 \%\end{array}$ & Rejected \\
\hline
\end{tabular}

\section{Conslusion}

The calculation of accuracy level generates that Modified Altman and Ohlson Models are the most accurate models compared to Springate, Zmijewski, and Grover. Both models have a prediction accuracy rate of $90.91 \%$ and an error measurement of 9.09\%. The Zmijewski Model has an accuracy rate and error measurement of $86.36 \% 13.64 \%$, respectively, followed by Grover Model with an accuracy rate of $81.82 \%$ and an error measurement of $18.18 \%$. Springate Model is the worst prediction model with an accuracy rate of $63.64 \%$ and the highest error measurement of $36.36 \%$. These are in accordance with the Kruskal Wallis test which states that all models have a significant difference.

This study will be very relevant for further researchers who are concerned with how to measure the level of financial difficulty in coal mining sector companies listed on the Indonesia Stock Exchange (IDX) for the 2019-2021 period beyond.

Funding: "This research received no external funding."

Acknowledgements: Thank my wife, for her tremendous support while writing this article.

Conflicts of Interest: The authors declare no conflict of interest.

\section{References}

[1] Altman, E. I. (1968). Financial Ratios, Discriminant Analysis and the Prediction of Corporate Bankruptcy. The Journal of Finance, $23(4), 589$. https://doi.org/10.2307/2978933

[2] Altman, E. I., Iwanicz-Drozdowska, M., Laitinen, E. K., \& Suvas, A. (2017). Financial Distress Prediction in an International Context: A Review and Empirical Analysis of Altman's Z- Score Model. Journal of International Financial Management \& Accounting, 28(2), 131-171. https://doi.org/10.1111/jifm.12053

[3] Ari Rachmad. (2021). PENGARUH ASPEK MANAJEMEN KEUANGAN DAERAH TERHADAP TRANSPARANSI PENGELOLAAN KEUANGAN DAERAH DI LUMAJANG. Journal of Islamic Science, Culture \&amp; Social Studies, 1 (1 SE-Articles), 92-112. http://journal.ascarya.or.id/index.php/iscs/article/view/13

[4] Edi, E., \& Tania, M. (2018). Ketepatan Model Altman, Springate, Zmijewski, dan Grover Dalam Memprediksi Financial Distress. Jurnal Reviu Akuntansi Dan Keuangan, 8(1), 79. https://doi.org/10.22219/jrak.v8i1.28

[5] Fatmawati, M. (n.d.). Penggunaan The Zmijewski Model, The Altman Model, dan The Springate Model Sebagai Prediktor Delisting. Jurnal Keuangan Dan Perbankan; Vol 16, No 1 (2012): January 2012DO - 10.26905/Jkdp.V16i1.1046. https://jurnal.unmer.ac.id/index.php/jkdp/article/view/1046

[6] Hungan, A., \& Sawitri, N. (2018). Analysis of Financial Distress with Springate and Method of Grover in Coal In BEI 2012 - 2016. International Business and Accounting Research Journal, 2. https://doi.org/10.15294/ibarj.v2i2.39

[7] Imelda, E., \& Alodia, I. (2017). Analysis of Altman Model and Ohlson Model in Predicting Financial Distress of Manufacturing Companies in the Indonesia Stock Exchange. Indian-Pacific Journal of Accounting and Finance, 1(1), 51-63. https://doi.org/10.52962/ipjaf.2017.1.1.4

[8] Kida, T. (1980). An Investigation into Auditors' Continuity and Related Qualification Judgments. Journal of Accounting Research, $18(2), 506$. https://doi.org/10.2307/2490590

[9] Maina, F., \& Sakwa, M. (2010). Understanding Financial Distress Among Listed Firms In Nairobi Stock Exchange: A Quantitative Approach Using The Z-Score Multi-Discriminant Financial Analysis Model.

[10] Mumford, M. (2003). Corporate Governance and Financial Distress: When Structures have to change. Corporate Governance: An International Review, 11, 52-64. https://doi.org/10.1111/1467-8683.00301

[11] Mutchler, J. F. (1985). A Multivariate Analysis of the Auditor's Going-Concern Opinion Decision. Journal of Accounting Research, $23(2), 668$. https://doi.org/10.2307/2490832

[12] Piscestalia, N., \& Maswar, P. P. (2019). Analisis Perbandingan Model Prediksi Financial Distress dengan Model Springate, Ohlson, Zmijewski, dan Grover. Jurnal Ilmu Dan Riset Akuntansi, 8(6), 2-17.

[13] Priambodo, D., \& Pustikaningsih, A. (2018). Analisis Perbandingan Model Altman, Springate, Grover, dan Zmijewski dalam Memprediksi Financial Distress (Studi Empiris pada Perusahaan Sektor Pertambangan yang Terdaftar di Bursa Efek Indonesia Periode 2012-2015). Jurnal Pendidikan Akuntansi, 6(4), 1-10.

[14] Primasari, N. S. (2018). ANALISIS ALTMAN Z-SCORE, GROVER SCORE, SPRINGATE, DAN ZMIJEWSKI SEBAGAI SIGNALING FINANCIAL DISTRESS (Studi Empiris Industri Barang-Barang Konsumsi di Indonesia). Accounting and Management Journal, 1(1). https://doi.org/10.33086/amj.v1i1.70

[15] Puspita Sari, E. W. (2015). Penggunaan Model Zmijewski, Springate, Altman Z-Score Dan Grover Dalam Memprediksi Kepailitan Pada Perusahaan Transportasi Yang Terdaftar Di Bursa Efek Indonesia. Jurnal Fakultas Ekonomi Dan Bisnis Universitas Dian Nuswantoro, 1-18.

[16] Safitri, A., \& Hartono, U. (2014). Uji Penerapan Model Prediksi Financial Distress Altman, Springate, Ohlson dan Zmijewski pada Perusahaan Sektor Keuangan di Bursa Efek Indonesia. Jurnal Ilmu Manajemen, 2(2), 328-337.

[17] Salim, M., \& Sudiono. (2017). AN ANALYSIS OF BANKRUPTCY LIKELIHOOD ON COAL MINING LISTED FIRMS IN THE INDONESIAN STOCK 
EXCHANGE: AN ALTMAN, SPRINGATE AND ZMIJEWSKI APPROACHES. Eurasian Journal of Economics and Finance, 5, 99-108. https://doi.org/10.15604/ejef.2017.05.03.008

[18] Whitaker, R. B. (1999). The early stages of financial distress. Journal of Economics and Finance, 23(2), $123-132$. https://doi.org/10.1007/BF02745946

[19] Widyanty, W. (2018). Analisis Perbandingan Model Altman, Springate, Zmijewski, Dan Ohlson Dalam Memprediksi Financial Distress (Studi Kasus Pada Perusahaan LQ-45 BEI 2013-2014) [Universitas Mecu Buana Jakarta]. https://repository.mercubuana.ac.id/38851/

[20] Wruck, K. H. (1990). Financial distress, reorganization, and organizational efficiency. Journal of Financial Economics, $27(2), 419-444$. https://doi.org/10.1016/0304-405X(90)90063-6

[21] Zainal Abidin Putera, F. Z., Swandari, F., \& Dewi, D. M. (2016). Perbandingan Prediksi Financial Distress dengan Menggunakan Model Altman, Springate dan Ohlson. Jurnal Wawasan Manajemen, 4(3), 217-229. https://doi.org/http://dx.doi.org/10.20527/jwm.v4i3.96 